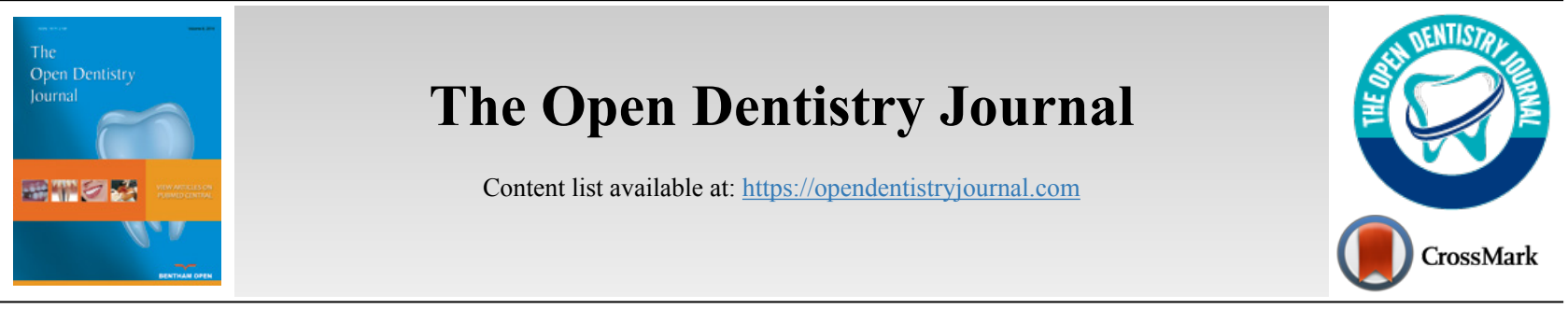

RESEARCH ARTICLE

\title{
Knowledge, Attitude, Practice, Motives and Barriers Towards Scientific Research among Dentists and Dental Students in Saudi Arabia
}

\author{
Somaya Abdulrahman ,"*, Khalid Aboalshamat ${ }^{2}$, Malak Muthana ${ }^{3}$, Ghaida Sait ${ }^{3}$, Nuran Bantan ${ }^{3}$, Shuruq Hafiz ${ }^{3}$, Renad \\ Mahrous $^{3}$ and Aishah Alsuhaqi ${ }^{3}$ \\ ${ }^{l}$ Department of Dentistry, Faculty of Dentistry, Umm Al-Qura University, Makkah, Saudi Arabia \\ ${ }^{2}$ Department of Preventive Dentistry, Dental Public Health Division, Faculty of Dentistry, Umm Al-Qura University, Makkah, Saudi Arabia \\ ${ }^{3}$ Department of Dentistry, Alfarabi College, Jeddah, Saudi Arabia
}

\begin{abstract}
:
Background:

Research is crucial for the scientific progress of the health of individuals, communities, and systems. The aim of this study was to assess the knowledge, attitude, motives and barriers among dentists and dental students in the western region of Saudi Arabia.

Objective:

This study aims to assess the level of knowledge, attitude, motives and barriers toward scientific research among dentists and dental students in the western region of Saudi Arabia.

Methods:

We conducted a cross-sectional study of 467 dentists and dental students using a convenience sampling method from seven dental colleges, major governmental and private dental clinics in the Western region of Saudi Arabia. We used a validated self-report questionnaire to collect data and assess the knowledge of, attitude towards and barriers to scientific research.

Results:

The participants (who are dentists and dental students) have a total knowledge score of $\mathrm{m}=4.57, \mathrm{SD}=2.46$, which is slightly lower than the midpoint. Participants who work in governmental clinic were significantly $(F(2,464)=13.71, p<0.001)$ more knowledgeable than those who worked in private clinic and the students. Most participants had positive general and personal attitudes toward scientific research. Of the participants, $40.5 \%$ to $60.4 \%$ were involved in research activities, and $37.3 \%$ have submitted or published scientific articles. The most common motive for scientific research was receiving credit for post-graduate application $(58.46 \%)$. The most common organizational barrier to conduct a research was the difficulty of finding research supervisor (39.19\%) and lack of time due to work overload $(32.55 \%)$. While most common personal barriers were lack of knowledge/skills (38.76\%), lack of personal time $(36.83 \%)$ and receiving credit for postgraduate application.

\section{Conclusion:}

Saudi dentists and dental students had a moderate level of knowledge and practice in research, but their attitude was highly positive. More efforts are needed to facilitate scientific dental research including supervisors' availability and time allocation for research. The study has some limitations including using convenience sample from one region and self-report questionnaire that decreases the external validity of the study and increases the potential for self-reported biases.
\end{abstract}

Keywords: Scientific research, Knowledge, Attitude, Practice, Motives, Barriers, Dental students, Dentists, Saudi Arabia.

\begin{tabular}{ll|l|l} 
Article History & Received: June 8, 2020 & Revised: October 25, 2020 & Accepted: November 17, 2020
\end{tabular}

\section{INTRODUCTION}

Health research is defined as synthesizing new knowledge via scientific methods to reveal and deal with health issues [1].

* Address correspondence to this author at the Department of Dentistry, Faculty of Dentistry, Umm Al-Qura University, Makkah, Saudi Arabia; Tel: +966555514344; E-mail: Somaya.a@outlook.com
Healthcare providers, especially physicians must have adequate knowledge of and skills for scientific research [2, 3] for optimal practice and high quality and delivery of healthcare services [4]. Health care scientific research is essential for diagnosis and treatment of oral disease and maintenance of oral health. In fact, it is considered a fundamental competency and one of the significant domains in the health care curriculum in 
medical education [5 - 7].

Many studies have been conducted to assess the knowledge and attitude of health professionals and medical students toward scientific research [8 - 13]. In contrast, these types of studies among dental students are scarce. Some studies assessed knowledge of dental professionals about research and found it to be between $52.3 \%$ to $56.7 \%$ among the Indian dentists [14] and $56.9 \%$ of Malaysian dental students had a moderate level of knowledge [15]. In Riyadh, Saudi Arabia, only one study assessed the level of knowledge in 10 questions and found the average of correct answer to be 3.36 [16]. The attitude toward dental scientific research varied according to the country and items to be measured, but many studies in general had a positive attitude such in India [14], South Africa [17] and Dammam, Saudi Arabia [18]. Also, it should be noticed that research is mandatory in some dental colleges, while it is not in others [17, 18]. For example, in dental colleges, University of Dammam, Saudi Arabia, the research is mandatory during the internship [18]. In Malaysia, 5.8\% did publication in high indexed journal [15]. However, around $21.2 \%$ to $32.5 \%$ did submit or have accepted papers for publication $[16,19]$. It should be highlighted that each of the previous studies in Saudi Arabia was conducted among students in a single governmental university, reducing the external validity of such a study. Also, this study did not include graduated dentists.

Literature reported several barriers toward conducting research among dental professionals such as lack of interest by faculty members, technique problems, lack of undergraduate courses, lack of interest, workload, lack of knowledge, insufficient mentors, personal and familial commitment [14, 18]. However, it is found with different percentages in different researchers.

As many articles highlight the importance of research to the undergraduate medical students $[8,20$ - 22]. Whereas, few studies were done among dental students and dentists investigating a larger geographical area. Thus, the aim of this study was to assess the knowledge, attitude, practice, motives and barriers among dentists and dental students in the western region of Saudi Arabia.

\section{MATERIALS AND METHODS}

This is a cross-sectional study aimed to assess the knowledge, attitudes, practice, motives and barriers towards research among dentists and dental students in the western region, Saudi Arabia. The participants were recruited from governmental and private dental colleges from Umm Al-Qura University, Taibah University, Taif University, King Abdulaziz University, Ibn Sina dental college, Alfarabi dental colleges and Al-Battarjee Medical College. Data was also collected from major governmental and private hospitals. A convenience sampling method was used. The inclusion criteria included dentists, interns and dental students in their $4^{\text {th }}$ or $5^{\text {th }}$ or $6^{\text {th }}$ academic year. The exclusion criteria include students in the $1^{\text {th }}, 2^{\text {nd }}, 3^{\text {rd }}$ year and retired dentists.

The questionnaire was validated by a pilot study of 20 undergraduates, dental interns and dentists. The validation included language, content, organization, and logical flow. The data were collected, tabulated and analysed using the SPSS version 23 (IBM Corp., Armonk, NY, USA). ANOVA, t-test and linear regression were used to compare participants' responses from the questionnaire. A statistical significance level at 0.05 will be used. The sample size was calculated by using $50 \%$ prevalence estimation, $5 \%$ as the precision level and $95 \%$ as the confidence interval, resulting in a minimum sample size of 385 participants. A total of 600 participants were invited to overcome the expected dropout rate.

Participants signed the study consent before receiving a hard copy of the anonymous and voluntary self-administered questionnaire at their own time. The questionnaire took four to six minutes to answer. The questionnaire was delivered by members of the research team who were available to answer any questions from the participants when needed.

The content of questionnaire was adapted from the previous studies [8, 14, 15, 23 - 25], and modified for this study. It comprised of 39 items divided into six sections. The first section included demographic data. The second section contained 10 Multiple Choice Questions (MCQ) assessing the respondent's knowledge about research (detention of Scientific research, literature review, best sampling method, sampling method, null hypothesis and referencing). Following the completion of this section, a total knowledge score was generated. The third section had eight general statements and five personal statements to assess participants' attitude toward research. This section was answered by five-point Likert scale ranging from strongly disagree to strongly agree. The fourth section assessed the scientific research practice with a range of yes or no questions. The fifth section of the questionnaire inquired about the motivation to conduct research. The sixth section investigated the institutional and personal barriers to conduct a scientific research. Both the fifth and sixth sections contained multiple answers where participants can choose more than one answer.

\section{RESULTS}

Data were collected from 467 respondents to 600 invitations (response rate of $66.83 \%$ ). Participants' mean (m) age was 27.95 with a Standard Deviation (SD) of 5.76. Their demographic data are detailed in Table 1.

Participants were asked ten questions about their knowledge regarding scientific research, their answers are detailed in Table 2. When correct answers were summed, the total correct answers were $\mathrm{m}=4.57, \mathrm{SD}=2.46$, with a possible score from 10 as the highest knowledge score and zero as lowest knowledge score.

Using ANOVA and Tukey's post hoc test, there was a significant relationship between total knowledge score and working place $(\mathrm{F}(2,464)=13.71, \mathrm{p}<0.001)$, as participants who work in the governmental clinic has total research knowledge score $(m=5.65, \mathrm{sd}=2.4)$ significantly higher than those who work in private clinics $(\mathrm{m}=4.01, \mathrm{sd}=2.19)$ or the student $(\mathrm{m}=4.4, \mathrm{sd}=2.49)$. However, there was no significant difference between those who work in private clinics with the students. Also, using t-test, ANOVA and linear regression tests, there was no relationship between knowledge score and age, gender and nationality.

Participants' different attitudes toward scientific research is shown in Tables $\mathbf{3}$ and $\mathbf{4}$. 
Table 1. Demographic data of the participants $(n=467)$.

\begin{tabular}{|c|c|c|c|}
\hline \multicolumn{2}{|r|}{ Variable } & \multirow{2}{*}{$\begin{array}{c}\text { Count } \\
176\end{array}$} & \multirow{2}{*}{$\begin{array}{c}\% \\
37.7 \%\end{array}$} \\
\hline Gender & Male & & \\
\hline & Female & 291 & $62.3 \%$ \\
\hline \multirow[t]{2}{*}{ Nationality } & Saudi & 370 & $79.2 \%$ \\
\hline & Non-Saudi & 97 & $20.8 \%$ \\
\hline \multirow[t]{3}{*}{ Current Hospital Working } & Private clinic & 115 & $24.6 \%$ \\
\hline & Governmental hospital & 98 & $21 \%$ \\
\hline & Student (college clinics) & 254 & $54.4 \%$ \\
\hline \multirow[t]{8}{*}{ Academic Year } & $4^{\text {th }}$ year & 19 & $4.1 \%$ \\
\hline & $5^{\text {th }}$ year & 32 & $6.9 \%$ \\
\hline & $6^{\text {th }}$ year & 70 & $15 \%$ \\
\hline & Interns & 132 & $28.3 \%$ \\
\hline & Post-Graduate & 12 & $2.6 \%$ \\
\hline & Dentist & 132 & $28.3 \%$ \\
\hline & Specialist & 48 & $10.3 \%$ \\
\hline & Consultant & 22 & $4.7 \%$ \\
\hline \multirow[t]{7}{*}{ University of graduation } & Al-Battarjee & 24 & $5.1 \%$ \\
\hline & Alfarabi & 199 & $42.6 \%$ \\
\hline & Ibn Sina & 38 & $8.1 \%$ \\
\hline & King Abdualaziz & 68 & $14.6 \%$ \\
\hline & Umm Al-Qura & 38 & $8.1 \%$ \\
\hline & Taiba & 19 & $4.1 \%$ \\
\hline & Others & 81 & $17.3 \%$ \\
\hline
\end{tabular}

Table 2. Answers of the knowledge questions regarding scientific research $(n=467)$.

\begin{tabular}{|l|l|l|}
\hline \multicolumn{2}{|c|}{ Item } & \multicolumn{1}{c|}{ Correct choice } \\
\hline Scientific research is: & An investigation of scientific theories or question. \\
\hline What is referencing in scientific research? & Acknowledge source of the information. & 282 (60.4) \\
\hline Which one can be used in literature review? & Governmental document & 260 (55.7) \\
\hline Which one is a better sampling method? & simple random sampling & 250 (53.5) \\
\hline Which one has better research design quality & Longitudinal (cohort) & 225 (48.2) \\
\hline In the result section in an article, you can find: & Main results of the statistical analysis. & 210 (45) \\
\hline What is a literature review? & Gathering trusted information about similar studies. \\
\hline Which one sounds like a null hypothesis? & There is no difference in caries prevalence between males and female. \\
\hline What is the first step of the research process? & Formulating the research question. & 206 (44.1) \\
\hline Which can be an author in a scientific article? & Participated by ideas in the paper & 196 (42) \\
\hline
\end{tabular}

Table 3. Participants' general attitude regarding scientific research.

\begin{tabular}{|c|c|c|c|c|c|}
\hline Item & $\begin{array}{c}\text { Strongly Disagree } \\
\text { n }(\%)\end{array}$ & $\begin{array}{c}\text { Disagree } \\
\text { n }(\%)\end{array}$ & $\begin{array}{c}\text { Neutral } \\
\text { n }(\%)\end{array}$ & $\begin{array}{l}\text { Agree } \\
\text { n (\%) }\end{array}$ & $\begin{array}{c}\text { Strongly Agree } \\
\text { n (\%) }\end{array}$ \\
\hline Research is essential for improving health care using evidence $\square$ based processes. & $\begin{array}{c}54 \\
(11.6)\end{array}$ & $\begin{array}{c}19 \\
(4.1 \%)\end{array}$ & $\begin{array}{c}58 \\
(12.4 \%)\end{array}$ & $\begin{array}{c}74 \\
(15.8)\end{array}$ & $\begin{array}{c}262 \\
(56.1 \%)\end{array}$ \\
\hline Research is essential for improving patient care using evidence $\square$ based processes & $\begin{array}{c}40 \\
(8.6 \%)\end{array}$ & $\begin{array}{c}36 \\
(7.7 \%)\end{array}$ & $\begin{array}{c}58 \\
(12.4 \%)\end{array}$ & $\begin{array}{c}96 \\
(20.6 \%)\end{array}$ & $\begin{array}{c}237 \\
(50.7 \%)\end{array}$ \\
\hline Studying research method should be compulsory in undergraduate years. & $\begin{array}{c}32 \\
(6.9 \%)\end{array}$ & $\begin{array}{c}51 \\
(10.9 \%)\end{array}$ & $\begin{array}{c}99 \\
(21.2 \%)\end{array}$ & $\begin{array}{c}94 \\
(20.1 \%)\end{array}$ & $\begin{array}{c}191 \\
(40.9 \%)\end{array}$ \\
\hline Undergraduate students should participate in research. & $\begin{array}{c}33 \\
(7.1 \%)\end{array}$ & $\begin{array}{c}35 \\
(7.5 \%)\end{array}$ & $\begin{array}{c}98 \\
(21 \%)\end{array}$ & $\begin{array}{c}116 \\
(24.8 \%)\end{array}$ & $\begin{array}{c}185 \\
(39.6 \%)\end{array}$ \\
\hline Conducting a research is difficult. & $\begin{array}{c}39 \\
(8.4 \%)\end{array}$ & $\begin{array}{c}49 \\
(10.5 \%)\end{array}$ & $\begin{array}{c}150 \\
(32.1 \%)\end{array}$ & $\begin{array}{c}118 \\
(25.3 \%)\end{array}$ & $\begin{array}{c}111 \\
(23.8 \%)\end{array}$ \\
\hline
\end{tabular}


(Table 3) contd.....

\begin{tabular}{|c|c|c|c|c|c|}
\hline Item & \begin{tabular}{|} 
Strongly Disagree \\
n $(\%)$
\end{tabular} & \begin{tabular}{|c|} 
Disagree \\
$\mathrm{n}(\%)$
\end{tabular} & $\begin{array}{c}\text { Neutral } \\
\text { n }(\%)\end{array}$ & $\begin{array}{l}\text { Agree } \\
\text { n (\%) }\end{array}$ & $\begin{array}{c}\text { Strongly Agree } \\
\text { n }(\%)\end{array}$ \\
\hline Research is useful for future dental profession in general. & $\begin{array}{c}41 \\
(8.8 \%)\end{array}$ & $\begin{array}{c}35 \\
(7.5 \%)\end{array}$ & $\begin{array}{c}80 \\
(17.1 \%)\end{array}$ & $\begin{array}{c}107 \\
(22.9 \%)\end{array}$ & $\begin{array}{c}204 \\
(43.7 \%)\end{array}$ \\
\hline Research conduction secures a better chance for a residency position. & $\begin{array}{c}36 \\
(7.7 \%) \\
\end{array}$ & $\begin{array}{c}44 \\
(9.4 \%)\end{array}$ & $\begin{array}{c}108 \\
(23.1 \%) \\
\end{array}$ & $\begin{array}{c}118 \\
(25.3 \%) \\
\end{array}$ & $\begin{array}{c}161 \\
(34.5 \%) \\
\end{array}$ \\
\hline Research conduction secures better chance for taking post graduate programs. & $\begin{array}{c}35 \\
(7.5 \%)\end{array}$ & $\begin{array}{c}48 \\
(10.3 \%)\end{array}$ & $\begin{array}{c}84 \\
(18 \%)\end{array}$ & $\begin{array}{c}122 \\
(26.1 \%)\end{array}$ & $\begin{array}{c}178 \\
(38.1 \%)\end{array}$ \\
\hline
\end{tabular}

Table 4. Participants' personal attitude regarding scientific research.

\begin{tabular}{|c|c|c|c|c|c|}
\hline Item & $\begin{array}{c}\text { Strongly Disagree } \\
\text { n }(\%)\end{array}$ & $\begin{array}{c}\text { Disagree } \\
\text { n }(\%)\end{array}$ & $\begin{array}{c}\text { Neutral } \\
\text { n (\%) }\end{array}$ & $\begin{array}{l}\text { Agree } \\
\text { n (\%) }\end{array}$ & $\begin{array}{c}\text { Strongly Agree } \\
\text { n }(\%)\end{array}$ \\
\hline I want to participate in a scientific research as a co-author. & $\begin{array}{c}62 \\
(13.3 \%)\end{array}$ & $\begin{array}{c}31 \\
(6.6 \%)\end{array}$ & $\begin{array}{c}97 \\
(20.8 \%)\end{array}$ & $\begin{array}{c}98 \\
(21 \%)\end{array}$ & $\begin{array}{c}179 \\
(38.3 \%)\end{array}$ \\
\hline I want to participate in a scientific research as the first author. & $\begin{array}{c}49 \\
(10.5 \%)\end{array}$ & $\begin{array}{c}40 \\
(8.6 \%)\end{array}$ & $\begin{array}{c}89 \\
(19.1 \%)\end{array}$ & $\begin{array}{c}88 \\
(18.8 \%)\end{array}$ & $\begin{array}{c}201 \\
(43 \%)\end{array}$ \\
\hline I want to participate in a scientific research as data collector. & $\begin{array}{c}52 \\
(11.1 \%)\end{array}$ & $\begin{array}{c}42 \\
(9 \%)\end{array}$ & $\begin{array}{c}114 \\
(24.4 \%)\end{array}$ & $\begin{array}{c}124 \\
(26.6 \%)\end{array}$ & $\begin{array}{c}135 \\
(28.9 \%)\end{array}$ \\
\hline I want to attend lectures (theoretical) about scientific research. & $\begin{array}{c}50 \\
(10.7 \%)\end{array}$ & $\begin{array}{c}58 \\
(12.4 \%)\end{array}$ & $\begin{array}{c}98 \\
(21 \%)\end{array}$ & $\begin{array}{c}97 \\
(20.8 \%)\end{array}$ & $\begin{array}{c}164 \\
(35.1 \%)\end{array}$ \\
\hline I want to attend hands-on workshop (practical) about scientific research. & $\begin{array}{c}52 \\
(11.1 \%)\end{array}$ & $\begin{array}{c}32 \\
(6.9 \%)\end{array}$ & \begin{tabular}{|c|}
80 \\
$(17.1 \%)$
\end{tabular} & $\begin{array}{c}104 \\
(22.3 \%)\end{array}$ & $\begin{array}{c}199 \\
(42.6 \%)\end{array}$ \\
\hline
\end{tabular}

Participants were asked questions about scientific research practice, their answers are detailed in Table 5. Participants'

motives and barriers regarding scientific research are detailed in Figs. (1-3).

Table 5. Participants' scientific research practice.

\begin{tabular}{|c|c|c|}
\hline Statement & $\begin{array}{c}\text { Yes } \\
\text { n (\%) }\end{array}$ & $\begin{array}{c}\text { No } \\
\text { n (\%) }\end{array}$ \\
\hline Was it mandatory to participate in research in your undergraduate curriculum? & $308(66 \%)$ & $159(34 \%)$ \\
\hline Did you attend research course within your undergraduate curriculum/ internship years in faculty? & $291(62.3 \%)$ & $176(37.7)$ \\
\hline Did you attend research course outside of your college? & $233(49.9 \%)$ & $234(50.1 \%)$ \\
\hline Did you do submit a research proposal? & $281(60.2 \%)$ & $186(39.8 \%)$ \\
\hline Did you participate in research as a data collector? & $282(60.4 \%)$ & $185(39.6 \%)$ \\
\hline Did you participate in research before in your dental college? & $200(42.8 \%)$ & $267(57.2 \%)$ \\
\hline Did you participate in research before outside your college? & $189(40.5 \%)$ & $278(59.5 \%)$ \\
\hline Do you have scientific publication(s) that was/were published or submitted for publication? & $174(37.3 \%)$ & $293(62.7 \%)$ \\
\hline Did you present a poster in a scientific conference before? & $181(38.8 \%)$ & $286(61.2 \%)$ \\
\hline
\end{tabular}

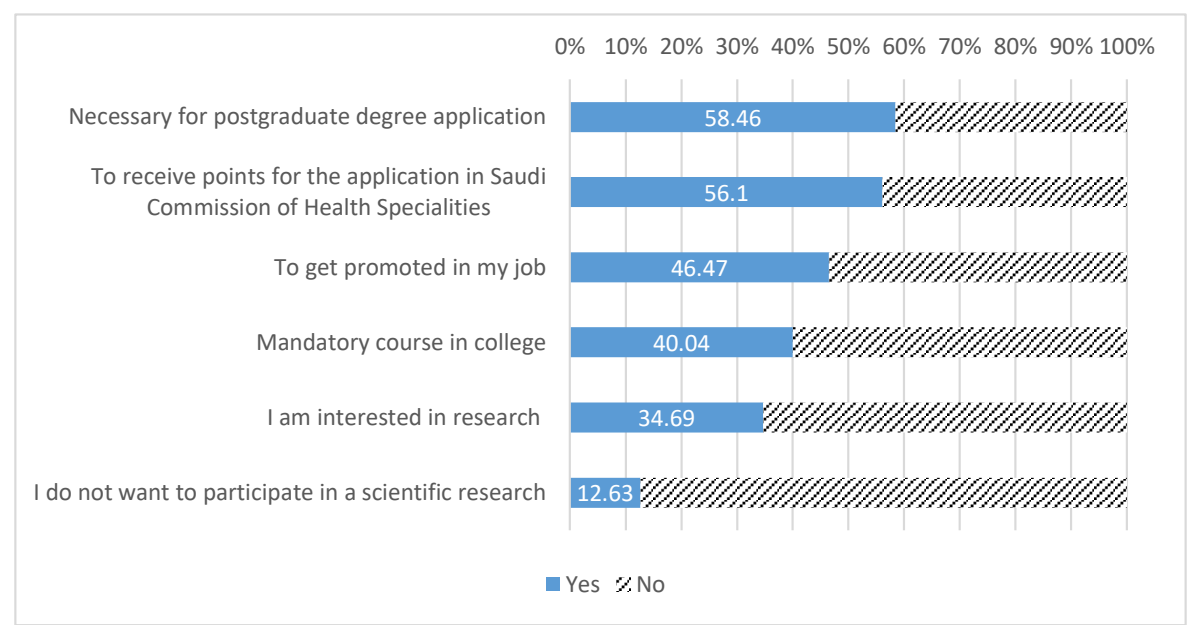

Fig. (1). The percentage of participants' motives to participate in scientific research. 


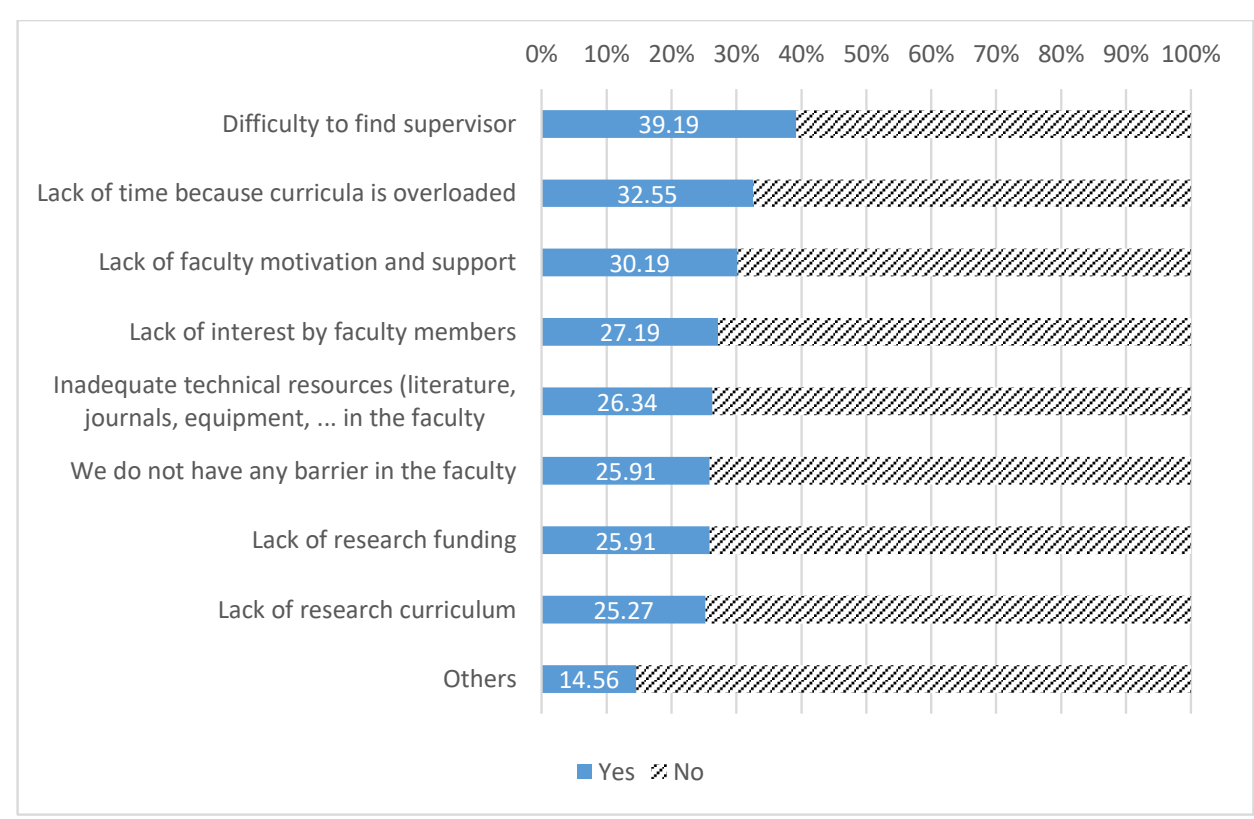

Fig. (2). The self-reported barriers of faculty to participate in research.

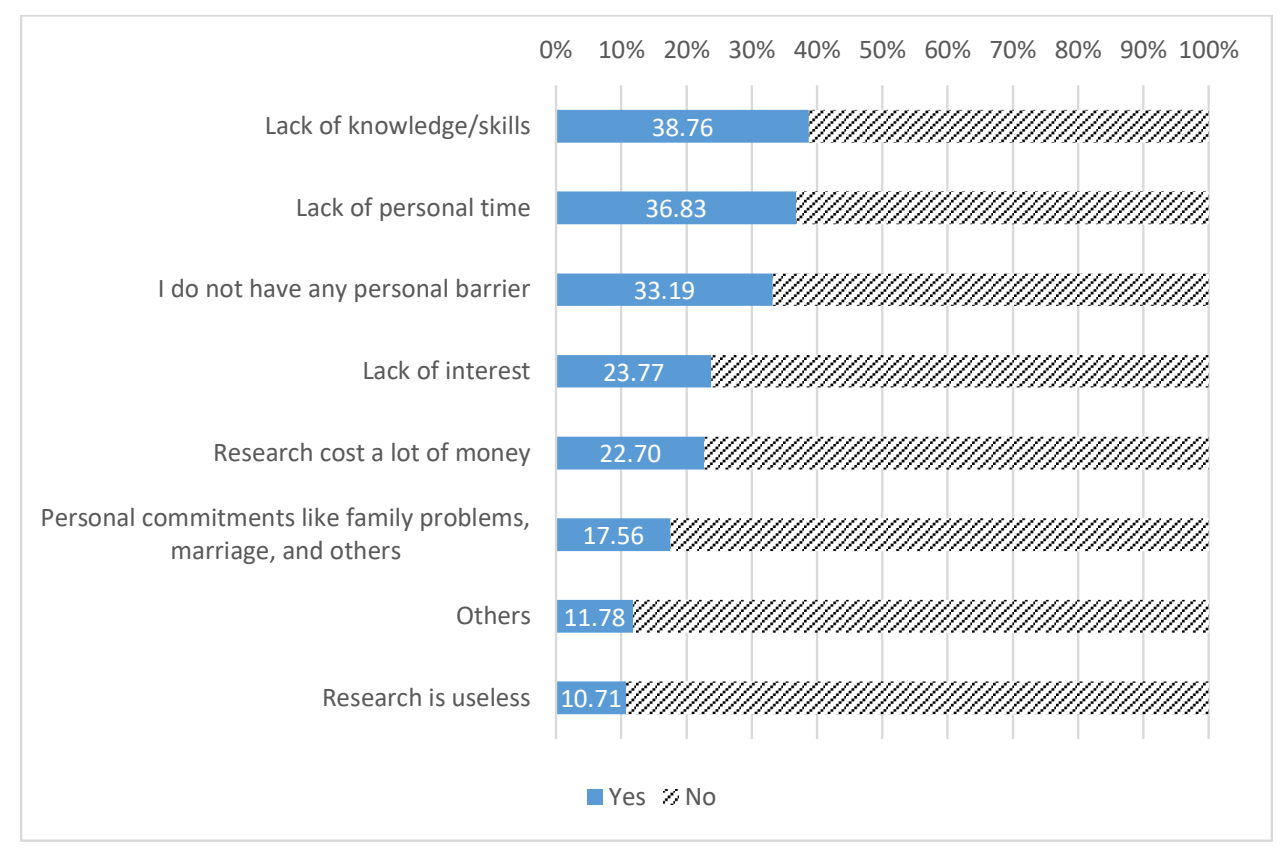

Fig. (3). The self-reported personal barriers to participation in research.

\section{DISCUSSION}

This study aimed to assess the level of knowledge, attitude, practice, motives and barriers toward scientific research among dentists and dental students in the Western region, Saudi Arabia. Participants' knowledge was slightly lower than the midpoint. Around two-third knew what scientific research is, but only one-fourth were able to know who could be an author of a scientific article. Participants who work in governmental clinics were more knowledgeable than those who work in private clinics and the students. Most participants had a positive general and personal attitude towards scientific research. Around $60 \%$ of the participants did participate in a research proposal or data collection, but around $60 \%$ did not have a publication nor a scientific poster. The most common motive for scientific research was post-graduated application and points in the application for Saudi Commission of Health Specialities (SCFHS). The most common organizational barrier to conduct research was finding a research supervisor, while lack of knowledge, skills and time were the most common personal barriers.

The moderate level of knowledge in this study was lower than a study in India where the average percentage of correct responses was 54\% among post-graduate dentists [14]. Also, in the Malaysian study, $56.9 \%$ of respondents had a moderate 
level of knowledge [15]. Our results showed a higher level of knowledge $(\mathrm{m}=4.57, \mathrm{SD}=2.46$, out of 10$)$ than a previous study in Riyadh, Saudi Arabia that had a score of $(\mathrm{m}=3.36, \mathrm{sd}=1.76)$ out of 10 [16]. None of the other studies in Saudi Arabia [18, 19] assess the scientific knowledge of dentists or dental students. This may be due to different levels of education between cities and countries. In addition, our knowledge assessment tool was different from those in other studies, as our study used different questionnaire set than those in the previous studies $[14,16]$. Nevertheless, it should be noticed that the questions in our study and previous studies can be considered the basic question in scientific research. In another word, this moderate level of knowledge might be overestimated. A further study is needed with a sophisticated tool to measure scientific research in-depth for a more precise result.

Regarding attitude assessment, the percentage of agree or strongly agree ranged between $55.5 \%$ to $71.9 \%$. In general, our results were similar to those of studies in India [14], South Africa [17] and Saudi Arabia [18] showing that the majority have a positive attitude towards scientific research. However, it was difficult to compare item by item due to the differences in questions asked and method of assessment. One of the commonly measured items was the importance of research, as $71.9 \%$ of our participants agree or strongly agree on this point. In a prior research in Dammam, Saudi Arabia [18], 60\% to $100 \%$ agreed on the importance of research. Also, in our study, $66.6 \%$ agree or strongly agree to the usefulness of research in dental profession in the future, while the percentage was $87 \%$ to 100 in South Africa [17], and $60 \%$ to $100 \%$ in Dammam [18]. indicated a high level of positive attitude towards research in the Western region on Saudi Arabia. Nevertheless, there was a considerable percentage for those who do not see the importance of research. In fact, many studies including the Saudi one indicated that research was not a major career goal in studying dentistry $[19,26,27]$. This can direct us to assume that scientific research might be important to many dentists and dental students but is not the main interest.

Regarding to practice scientific research, there was a variability in the data. Our study involved data from the Western region of Saudi Arabia that include seven dental colleges, so data were obtained from different centers. In our study, $66 \%$ had mandatory scientific research in their undergraduate, while in South Africa [17] $72 \%$ to $92 \%$ reported that to be mandatory. In Dammam [18], authors indicated that research project was only mandatory during internship. Our data indicated that $40.5 \%$ to $60.4 \%$ of the participants participated in research activity (writing proposal or collecting data). This was lower than the percentage in South Africa (52\% to $98 \%$ ) [17] but similar to previous studies in the US (34\% to 63\%) [28] and Jeddah, Saudi Arabia (40.7\% to $59.7 \%$ ) [19]. More importantly, $37.3 \%$ of participants had a scientific publication, or had submitted a paper for publication. This was similar to a previous study in Riyadh (32.5\%) [16], but higher than the results in Jeddah $(21.2 \%)$ [19] and a previous study in Malaysia (5.8\%) [15]. In our study, 49.9\% to $62.3 \%$ attended a research course, while it ranged from $30 \%$ to $100 \%$ in Riyadh [16] and Dammam, Saudi Arabia [18]. This reflects the different influences of the educational, organizational system into dental professional experience in scientific research. However, it can be noticed that percentages for the studies in Saudi Arabia do not have a significant difference. In fact, this shows that the research experience in Saudi Arabia is of moderate level in general.

An interesting finding in our study was the motivation to conduct research for receiving SCFHS points on the postgraduate application. It was noticed among the university students that many of them are conducting research for this reason. This might be the first article to document this point. This is important point to highlight, as future studies may explore type, quality, and authenticity in such publication. Also, our results showed that $12.63 \%$ were not interested in research publication; this is similar to a previous study in Dammam that showed that $15.63 \%$ were not interested in research as well [18], but lower than the percentage in Riyadh $(36.4 \%)$ for the same item. This may be due to the difference in location-specific institutional/personal barriers that discourage dentists or dental students from conducting a research.

Our result showed that the most common institutional barrier was lack of supervisor, and lack of time due to work overload. While the most common personal barriers were lack of skills/ knowledge and lack of personal time. In fact, lack of time has been mentioned as the main barrier in the previous studies in the US [28], India [14] and Riyadh [16]. However, other studies had different main barriers, such as lacking both interest and opportunities toward research during dental school in China [29]. Also, the main barrier was the absence of adequate technical resources to conduct research in India [14]. Once again, this reflects cross cultural difference for participation in research among dental professionals. In addition, students are struggling to pay for dental school tuitions in several countries [30, 31]. Therefore, limited resources may serve as an obstacle for dental students to engage in research. In Saudi Arabia, education is free in governmental dental colleges, and some students get scholarship in private dental colleges, which might reduce their financial burden. Providing dedicated supervisors to dental students would be helpful to students for research and publication activities.

This study has some strengths, including the investigation of the Western region of Saudi Arabia including different cities and universities, in contrast to previous Saudi studies that mostly investigated one centre $[16,18,19]$. However, this study used a convenience sample and was performed only in western region of Saudi Arabia, so it cannot be generalized to all of Saudi Arabia. We also used a self-report questionnaire, which increases self-reported biases. Future studies might be directed to be conducted on a national scale to an increased potential for bias.

\section{CONCLUSION}

Dentists and dental students had a moderate level of knowledge about scientific research. Most participants had a positive general and personal attitude toward scientific research. Many of them participated in research activity (writing proposal or data collection) but the majority did not publish or submitted article for publication. The most common 
motive for scientific research was post-graduation application and points in the application of Saudi Commission of Health Specialities (SCFHS). The most common organizational barrier to conduct research was finding research supervisor, while lack of knowledge, skills and time were the most common personal barriers. More efforts are needed to facilitate scientific dental research including supervisors mentoring and organizational/ university time allocation for research. Future studies might be directed to conduct investigation about research among dental professional on a national scale to increase the external validity of the study, and to investigate the type and quality of a published paper by Saudi dental professional.

\section{ETHICS APPROVAL AND CONSENT TO PARTICIPATE}

The approval has been obtained from the Institutional Review Board of the Faculty of Dentistry of Umm Al-Qura University Saudi Arabia, (No. 171-20).

\section{HUMAN AND ANIMAL RIGHTS}

Not applicable.

\section{CONSENT FOR PUBLICATION}

All patients signed informed consent forms prior to participating in this study.

\section{AVAILABILITY OF DATA AND MATERIAL}

Data were collected from the Dental Teaching Hospital of Umm Al-Qura University and private clinics in Mecca.

\section{FUNDING}

None.

\section{CONFLICT OF INTEREST}

The author declares no conflict of interest, financial or otherwise.

\section{ACKNOWLEDGEMENTS}

Declared none.

\section{REFERENCES}

[1] Commission on Health Research for Development. Health research: essential link to equity in development. USA: Oxford University Press 1990.

[2] Vairamani CR, Akoijam BS. Knowledge, attitude and perceived barriers towards conducting research among students in a medical college, India. Int J Community Med Public Health 2018; 5: 806-10. [http://dx.doi.org/10.18203/2394-6040.ijcmph20180273]

[3] Hebert RS, Levine RB, Smith CG, Wright SM. A systematic review of resident research curricula. Acad Med 2003; 78(1): 61-8. [http://dx.doi.org/10.1097/00001888-200301000-00012] [PMID: 12525411]

[4] Al-Halabi B, Marwan Y, Hasan M, Alkhadhari S. Extracurricular research activities among senior medical students in Kuwait: Experiences, attitudes, and barriers. Adv Med Educ Pract 2014; 5: 95-101. [PMID: 24812535]

[5] Zehra N, Hassaan A, Mushtaq S. Research amongst junior and senior medical students. Prof Med J 2015; 22(01): 117-2.

[6] Vujaklija A, Hren D, Sambunjak D, et al. Can teaching research methodology influence students' attitude toward science? Cohort study and nonrandomized trial in a single medical school. J Investig Med
2010; 58(2): 282-6.

[http://dx.doi.org/10.2310/JIM.0b013e3181cb42d9]

[PMID: 20130460]

[7] Abu-Zaid A, Alkattan K. Integration of scientific research training into undergraduate medical education: A reminder call. Med Educ Online 2013; 18(1): 22832.

[http://dx.doi.org/10.3402/meo.v18i0.22832] [PMID: 24149135]

[8] Amin TT, Kaliyadan F, Al Qattan EA, Al Majed MH, Al Khanjaf HS, Mirza M. Knowledge, attitudes and barriers related to participation of medical students in research in three Arab Universities. Educ Med J 2012; 4(1): 47-55.

[http://dx.doi.org/10.5959/eimj.v4i1.7]

[9] Khan H, Khawaja MR, Waheed A, Rauf MA, Fatmi Z. Knowledge and attitudes about health research amongst a group of Pakistani medical students. BMC Med Educ 2006; 6(1): 54. [http://dx.doi.org/10.1186/1472-6920-6-54] [PMID: 17081286]

[10] Bonner A, Sando J. Examining the knowledge, attitude and use of research by nurses. J Nurs Manag 2008; 16(3): 334-43. [http://dx.doi.org/10.1111/j.1365-2834.2007.00808.x] [PMID: 18324993]

[11] Vodopivec I, Vujaklija A, Hrabak M, Lukić IK, Marusić A, Marusić M. Knowledge about and attitude towards science of first year medical students. Croat Med J 2002; 43(1): 58-62.

[PMID: 11828562]

[12] Campisi J, Finn KE. Does active learning improve students' knowledge of and attitudes toward research methods? J Coll Sci Teach 2011; 40(4)

[13] Burgoyne LN, O'Flynn S, Boylan GB. Undergraduate medical research: The student perspective. Med Educ Online 2010; 15(1): 5212 .

[http://dx.doi.org/10.3402/meo.v15i0.5212] [PMID: 20844608]

[14] Sharma N, Pramila M, Krishnamurthy A, Umashankar G, Ahuja N. Knowledge, attitude, and practices in research among postgraduate students in dental institutions in Bengaluru City, India. Journal of Indian Association of Public Health Dentistry 2014; 12(3): 189. [http://dx.doi.org/10.4103/2319-5932.144793]

[15] Kyaw Soe HH, Than NN, Lwin H, Nu Htay MNN, Phyu KL, Abas AL. Knowledge, attitudes, and barriers toward research: The perspectives of undergraduate medical and dental students. J Educ Health Promot 2018; 7: 23.

[http://dx.doi.org/10.4103/jehp.jehp_61_17] [PMID: 29629384]

[16] Habib SR, AlOtaibi SS, Abdullatif FA, AlAhmad IM. Knowledge and attitude of undergraduate dental students towards research. J Ayub Med Coll Abbottabad 2018; 30(3): 443-8. [PMID: 30465383]

[17] Grossman ES, Naidoo S. Final-year South African dental student attitudes toward a research component in the curriculum. J Dent Educ 2009; 73(11): 1306-12.

[http://dx.doi.org/10.1002/j.0022-0337.2009.73.11.tb04822.x] [PMID: 19910480]

[18] Khan SQ, Farooqi FA, Moheet IA, Rejaie AS. Attitude and experiences of undergraduate dental students and interns towards research. Saudi journal of medicine and medical sciences 2016; 4(2): 108.

[http://dx.doi.org/10.4103/1658-631X.178332]

[19] Alhazzazi TY, Bogari DF, Alzebiani NA, Hazzazi LW, Abed HH, AlHazmi N, et al. Research Interest Assessment Among Dental Students at King Abdulaziz University Faculty of Dentistry. 2016.

[http://dx.doi.org/10.15226/jdodt.2016.00160]

[20] Alghamdi KM, Moussa NA, Alessa DS, Alothimeen N, Al-Saud AS. Perceptions, attitudes and practices toward research among senior medical students. Saudi Pharm J 2014; 22(2): 113-7. [http://dx.doi.org/10.1016/j.jsps.2013.02.006] [PMID: 24648822]

[21] Al-Hilali SM, Al-Kahtani E, Zaman B, Khandekar R, Al-Shahri A, Edward DP. Attitudes of saudi Arabian undergraduate medical students towards health research. Sultan Qaboos Univ Med J 2016; 16(1): e68-73.

[http://dx.doi.org/10.18295/squmj.2016.16.01.012] [PMID: 26909216]

[22] Kharraz R, Hamadah R, Alfawaz D, Attasi J, Obeidat AS, Alkattan W, et al. Perceived barriers towards participation in undergraduate research activities among medical students at Alfaisal University-College of Medicine: A Saudi Arabian perspective. Medical teacher 2016; 38(sup1): S12-8.

[23] Ibrahim N, Fetyani DM, Bashwari J. Assessment of the researchoriented knowledge, attitude and practice of medical students and interns of the King Abdulaziz University, Jeddah and the adoption of a research-intervention educational program. Rawal Med J 2013; 38(4): 
432-9

[24] Pallamparthy S, Basavareddy A. Knowledge, attitude, practice, and barriers toward research among medical students: A cross-sectional questionnaire-based survey. Perspect Clin Res 2019; 10(2): 73-8. [http://dx.doi.org/10.4103/picr.PICR_1_18] [PMID: 31008073]

[25] Pawar DB, Gawde SR, Marathe PA. Awareness about medical research among resident doctors in a tertiary care hospital: A crosssectional survey. Perspect Clin Res 2012; 3(2): 57-61.

[http://dx.doi.org/10.4103/2229-3485.96446] [PMID: 22701821]

[26] Aggarwal A, Mehta S, Gupta D, et al. Dental students' motivations and perceptions of dental professional career in India. J Dent Educ 2012; 76(11): 1532-9.

[http://dx.doi.org/10.1002/j.0022-0337.2012.76.11.tb05416.x] [PMID: 23144490]

[27] Halawany HS, Binassfour AS, AlHassan WK, et al. Dental specialty, career preferences and their influencing factors among final year dental students in Saudi Arabia. Saudi Dent J 2017; 29(1): 15-23. [http://dx.doi.org/10.1016/j.sdentj.2016.12.001] [PMID: 28270705]

[28] Holman SD, Wietecha MS, Gullard A, Peterson JM. U.S. dental students' attitudes toward research and science: Impact of research experience. J Dent Educ 2014; 78(3): 334-48.

[http://dx.doi.org/10.1002/j.0022-0337.2014.78.3.tb05684.x] [PMID: 24609336]

[29] Ping W. Dental undergraduate students' participation in research in China: Current state and directions. Eur J Dent Educ 2015; 19(3): 177-84.

[http://dx.doi.org/10.1111/eje.12119] [PMID: 25661035]

[30] Matthew IR, Walton JN, Dumaresq C, Sudmant W. The burden of debt for Canadian dental students: Part 1. Review of the literature. J Can Dent Assoc 2006; 72(7): 635.

[PMID: 16978481]

[31] Nicholson S, Vujicic M, Wanchek T, Ziebert A, Menezes A. The effect of education debt on dentists' career decisions. J Am Dent Assoc 2015; 146(11): 800-7.

[http://dx.doi.org/10.1016/j.adaj.2015.05.015] [PMID: 26514885]

\section{C) 2020 Abdulrahman et al.}

This is an open access article distributed under the terms of the Creative Commons Attribution 4.0 International Public License (CC-BY 4.0), a copy of which is available at: (https://creativecommons.org/licenses/by/4.0/legalcode). This license permits unrestricted use, distribution, and reproduction in any medium, provided the original author and source are credited. 